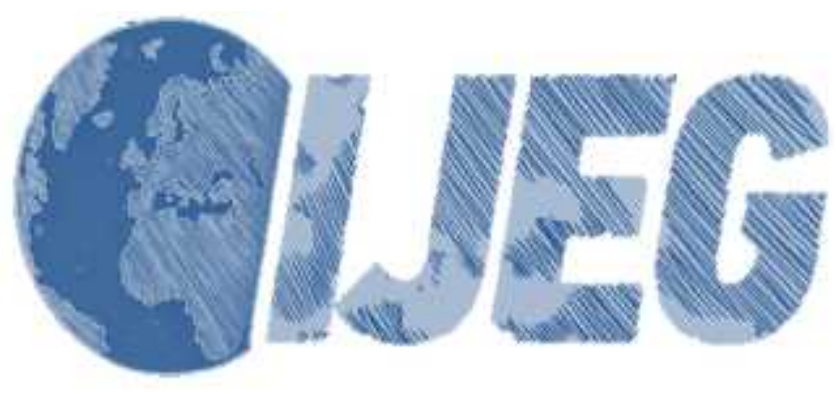

International Journal of Engineering and Geosciences (IJEG), Vol; 2; , Issue; 02, pp. 63-67, June, 2017, ISSN 2548-0960, Turkey, DOI: 10.26833 /ijeg.297223

\title{
EVALUATION OF LAND REFORM POLICIES IN TURKEY
}

\author{
Tayfun $\mathrm{Cay}^{1}$, Nuh Toklu ${ }^{2}$ and Omur Esen ${ }^{3}$
}

${ }^{1}$ Selçuk University, Engineering Faculty, Department of Geomatic Engineering, Konya, Turkey (tcay@ selcuk.edu.tr)

${ }^{2}$ General Directorate of Highways, Ankara, Turkey

${ }^{3}$ Selcuk University, Science Institute, Geomatic Engineering, Konya, Turkey (omuresen@ selcuk.edu.tr)

*Corresponding Author, Received: 10/03/2017, Accepted: 03/06/2017

\begin{abstract}
:
Turkeys agricultural policies of the European Union, World Bank, International Monetary Fund on a global scale, such as areas of activity by the organizations and groups, referral is made. Since the beganning of the Republic of Turkey, land reform has been different application. "On June the $11^{\text {th }} 1945$, a Law to Provide Farmers with Land enumerated 4753, Land and Agrarian Reform Law dated 1973 and Enumerated 1757, Agrarian Reform Law Regarding Land Regulations in Irrigation Areas, Land Protection \& Land Use Law enumerated as 5403/5578" applications have handled in within Turkey land reform. In region of the land reform applied, had been a lot of problem for example, lack of credit, absence of qualified personnel for giving information, etc. and had not gotten efficiency to expected performance and successed expectancy.

In this study, land reform, according to the particular application in the world have studied the similarities and differences. A viable model for our country's land reform was formed.
\end{abstract}

Keywords: Land Reform, Land Regulation, Land Use, Use of Rural Land. 


\section{INTRODUCTION}

An integrated reformist approach to regulate relation of man and soil is necessary to develop and improve rural areas. In Turkey, an agricultural structure with a feudal or semi feudal population, lack of sufficient land in many of the agricultural companies, and the presence of many farming families who do not have any fields but maintain their living through sharecropping and agricultural labor, is evident. Many farmer families with sufficient soil are engaged in an agricultural production which is not economic and ergonomic due to fragmentized fields, tilt, and false product selection.

Nowadays, we are in times in which policies are determined globally. Agricultural policies in Turkey are not an exception to this rule and are determined with the impact of organizations and groups operating on a global basis such as the European Union (EU), World Bank, and International Monetary Found. As a country trying to resettle on the one hand man-earth relations domestically and on the other hand trying to come to terms with the Common Agricultural Policies of the EU, a long term policy of Turkey to become a member state, and fulfill the demands regarding agriculture will make a revision of land, person, and property relations in rural areas inevitable.

Today one of the big biggest problems in the World is the comparison of assets and poverty. There are currently 350 billionaires in the world. According to David C. Korten, the annual income of $45 \%$ of the world's poorest population is equivalent to these billionaire's yearly income. This contrast is a result of the injustice in land ownership, lack of access to farmland, and distribution of goods.

According to Susan George's book "How the Other Half Die", in a world where millions of poor live , among all the land owners in the world only $2.5 \%$ have fields of 100 decare and all over the world about three quarters of all land are in the control of this 0.23 \% (Stibbe 1997). Land tenure research is itself a vast and complex area due to the large variation and complexity of land tenure systems, which has contributed to the specialization of land tenure researchers (Stein and Hosaena, 2016). There is little solid empirical evidence of the long-run impact of tenancy reforms, and limited understanding of whether economic actors use land markets to reduce or amplify the intended impact of these regulations (Besley et al.,2016).

If the factors necessitating and influencing land reform are to be investigated, concerns about permanent settlement efforts, land problem existence, development of villagers, industrialization and modern urbanization demands, ideological perspectives of the executives, and the consideration of the peasantry without land as a potential source of conflict can be mentioned. Hartvigsen (2014) presented an overview of land reform approaches and fragmentation issues in a Central and Eastern European context (for 25 countries), focusing on the causality between the chosen land reform approach and the resulting land fragmentation.

The use of land, among the key elements of agricultural production, as a tool of exploitation has increased the social pressure and thus the political pressure on land. Therefore "land reform" is constantly on the agenda. In the present study, land reform policies from Ottoman Times until today in Turkey, criteria leading to changes in these policies, and land reform policies, global agricultural polices, are analyzed.

\section{LAND \& AGRARIAN REFORM POLICIES OF THE REPUBLICAN PERIOD}

The initial approach of the Turkish Republic to the land issue can be summarized under three main headings (Toklu, 2010): foreigners,

1. Efforts to restrict property acquisition by

2. Efforts to reduce pressure on land to achieve industrialization together with modern urbanization,

3. Improving agriculture and abandoning peasantry with a feudal structure through democracy. In the early years of the republic, industrialization, modern urbanization, land reform efforts and attempts to solve the problems of agriculture were conducted in unison.

Article 87 of the Village Law enumerated as 442 and dated $18^{\text {th }}$ March 1924 prohibits the acquisition of land by foreign nationals within village boundaries. Furthermore, within the general restrictions introduced by item 35 of the Land Registry Law dated $22^{\text {nd }}$ December 1934 and enumerated 2644; foreign nationalities may have land ownership if they comply to the laws and regulations and fulfill the conditions of reciprocity. Item 36 of the same law stipulated that foreign nationalities may purchase independent farms out of the village boundaries up to 30 decare; yet, beyond that portion only if the government allows them to do so. Thus limitations were brought into this issue.

With approval of the Amendment in the Land Registry Law enumerated 5782 and dated $3^{\text {rd }}$ July 2008 by the Constitutional Court, all obstacles in land ownership by foreigners were resolved. Henceforth, all foreign nationalities as well as foreign companies having a legal personality established according to their laws in their countries can be titleholders in Turkey.

Use at most three levels of headings that correspond to chapters, sections and subsections. The first level headings for chapter titles should be in 10pt, bold, justified, and upper case font. Leave one-blank line before and after the first level headings, respectively.

\subsection{The Second Level Headings}

On June the $11^{\text {th }} 1945$, a Law to Provide Farmers with Land (Çiftçiyi Topraklandırma Kanunu (ÇTK)) enumerated 4753 and Land Festival enumerated 4760 was passed. The purpose of this law is determined 
as to provide land to farmers without or with insufficient land. Among the aims of the law was also to donate the farmers who were lacking the means of production with the necessary equipment. Furthermore, applications such as founding capital, business capital supply were brought to the agenda. The purpose of these laws were not only to eliminate structural problems in land ownership by dividing large estates into smaller pieces, but also providing the necessary support and help to improve agriculture and to take measures for constant taming of the soil for continuing production.

According to item 7 of the law, any piece of land not cultivated, cared for, and used economically according to local conditions for three consequent years without an acceptable excuse, will be considered by the Ministry of Agriculture as unprocessed and will be expropriated.

Land to be distributed primarily was public land, public property in the villages, and land to be acquired from dried lakes and marshy grounds. In the areas where these were insufficient, it was stipulated that private land was to be expropriated and then distributed. In general 5000 decare, in areas with scarce land above 2000 decare was to expropriated and then distributed. The most debated item of this law was item 17. According to this item, agricultural laborers, sharecroppers, and tenants without or with little land, could become owners of the land they have been working on. In a country like Turkey where sharecropping was practiced widely, this item would enable the confiscation the field of many large land owners.

A group of large landowners lead by Adnan Menderes, Emin Sazak and Cavit Oral, claimed the following about ÇTK: There is not a land scarcity problem in Turkey, if desired, arable land can be increased up to 3 times in Turkey. The current problem in Turkey arises from the fact that the goods of the farmers are sold cheaply and their necessitties purchased expensively. The greatest needs of the farmer are equipment with necessarry tools, increase of their credits, and the use of scientific methods in agriculture (Suicmez ve Güler 2005).

At the end of these political reactions, although there were other important reasons as well, The Democratic Party (DP) was founded under the leadership of large landowners separated from the CHP along with "Quarted Proposal" on the $12^{\text {th }}$ of June in 1945.

In 1950, the limit of land expropriation was increased from 500 decar to 5000 decar in the in Law to Provide Farmers with Land (ÇTK). During the time in wihich the law was practised, the provisions especially related to the expropriation were put out of commission, out of the 2.225.428 decar land distiributed to 446.825 families in the 8116 villages, 1540 decare of land was obtained through exproriation and only 540 decare within 1540 decare land was dispossesioned from private individuals.

As Law to Provide Farmers with Land (ÇTK) could not lead to the division of large pieces of land, the land distributed was moslty public porperty and in places where land is scarce and where there is no public land property suchas the Black Sea Region, distribution of land was minimal. In Southeastern Anatolia Region; however, large landowners prevented small commodity farming by passing to capitalist agriculture and maintained thus their political strength.

The most important reason why the Law to Provide Farmers with Land (ÇTK) did not yield the expected results was the the inability to organize farmers and the lack of cooperatives supporting them in every aspect.

\subsubsection{Land and Agrarian Reform Law dated 1973 and Enumerated 1757}

Within the scope of the Law to Provide Farmers with Land (ÇTK), public property land was distributed and hence the current land structure more deranged.

Land and Agrarian Reform Law dated 1973 and enumerated 1757 is the one regulating best the relation between man and land. It was only effective for five years until it was abolished five years later by the Constituinal Court of Turkey in terms of form. Unlike Law to Provide Farmers with Land (ÇTK), this law aimed to prevent further fraction of land not only distributed from public property but also land in the posession of private individuals, and it included interesting items limiting the use of grazing land and other lands for non agricultural activities. As this law was not reformulated within a year after it was cancelled by the Constituinal Court of Turkey, it was completely abolished on the 10th of May in 1978.

Land and Agrar Reform Law was in effect between the July, $19^{\text {th, }} 1973$ and $10^{\text {th }}$ of May 1978 and Şanliurfa had been chosen as a pilot area during this period. The underlying reasons for the selection of Şanlıurfa were; land distribution in that area was quite unjust and by resolving the injustice in land distribution and hence preventing migration to major cities, quite on top of agenda in those days, to contribute to the development of East and Southeast Anatolian Region. Resulting from the implementation of the law:

The results of the reform implementation in Şanliurfa province were as follows:

Out of the 697 villages in total, expropriation was conducted in 329 villages

Expropriated land: $1.616 \mathrm{~km}^{2}$

Number of villages land was ditributed to: 47

Number of families land was ditributed to: 1.218

Amount of land distirbuted: $231 \mathrm{~km}^{2}$

According to this data ,231 squarekilometer land was distributed to 1.218 families. $1.616 \mathrm{~km}^{2}$ land was expropriated (URL1).

To implement the Land and Agrar Reform law enumerated as 1757, the undersecratariat for Land and AgrarReform was established in 1973. 
During the period in which this law was effective, the Land and Agrarian Reform Undersecretary transferring subventions to the relevant instituions and organizations has made several social investments such as 45 health centers for social purposes, 3 high schools ,7 regional primary boarding schools, 1 feed plant, 190 irrigation wells, 132 miles village road, 80 bridges, drinking water pipes to 364 villages ,227 miles (km)provincial roads ,power transmission lines, and transformer stations possible (Anonymous 1995).

In order to realize objectives of Land and Agrar Reform Law enumerated as 1757 , to maintain the living of a family of five at provincial level throghout Turkey, 79-337 decare land for dryland agriculture and 32-106 decare for irrigated farming were determined as necessary. Although granting land to farmers was not realized due to the cancellation of the Law enumerated as 1757 , when the law enumerated as 3083 came into force in $1984,101-103$ decare public property land was distributed to 754 farmers families in 36 villages who were defined according to law no.1757 as potential farmers (Anonymous 1995).

\subsection{Agrarian Reform Law Regarding Land Regulations in Irrigation Areas (Law dated 1984 and enumerated 3083)}

Land and Agrarian reform law was repealed in 1978. On December the $1^{\text {st, }} 1984$ enumerated 3083 the "Agrarian Reform Law Regarding Land Regulations in Irregation Areas" came into force. In order to realise the objectives of this law "General Directorate for Agrarian Reform (TRGM)" was established in line with the law defining the role and function of Agrarian Reform General Directorate as published in the official Gazette No.18685 and dated March 5 $5^{\text {th }} 1985$ and enumerated 3155 .

The scope of this law is determined according to the decisions taken by the Council of Ministers and proposals made by the relevant ministry.

"Agrarian Reform Law Regarding Land Regulations in Irrigation Areas" includes land reform within its form. This law also foresees land expropriation from land owners with vast lands above the determined norm and provision to the farmers with no or insufficient land. For this purpose, expropriation will be conducted on areas ten times above the foreseen provision amounts and the facilites on them with the exception of vineyard, garden, forested land, and model businesses belonging to legal entities.

In line with the article 44 of the current 1982 constituiton in force stating: "The state takes necessary cautions for protecting and developing the cultivation land, avoids its loss by erosion and provides land to peasant who are agriculturists without or insuficient land" item b of the law enumerated 3083 land is to be distributed. In the areas where this law was applied, 11399 agriculturist farmer families in 147 villages were distributed 735741 decar public land between 1987 and 2006. Until 2013, additionally 88442 decar public land was distributed to 13734 agriculturist farmer families in 176 villages. Land is still distributed in areas where this law is applied. Within this framework, in the application areas during the 2005-2006 rental period 319 farmers without or insufficient land were rented 431687 decar land. During 2000-2012; however, to 143391 agricultural farmers 683163 hectar land for an amount of 66221637 TL (1 \$=1,80 TL) was rented (URL 2).

According to the law enumerated 3083 " General Directorate fo Agrarian Reform (TRGM)" continues, either with or without the consent of the legal entities, land consolidation in the areas where the law is put into practice. Until so far (between 2003-2012 land consolidation has been conducted for 2503602 hectar land by TRGM. Land consolidation will be conducted in the coming 5 years in an area of 2 million hectar (Anonymous, 2012).

\subsection{Land Protection \& Land Use Law enumerated as 5403/5578}

In Turkey, legal regulations about land protection have only been items, statetments, and regulations until 2005. In 2005 for the first time a code solely for "Land Protection and Land Use " enumerated 5403 was put into force (Ulger and Cay 2012).

The aim of this law is; saving land by preventing the loss of its features by natural or artificial ways and developing and determining planned land use based on principles of sustainable development.

This law generally determines correct use of land by determining soil type and land presence, classification of agricultural areas, determining land parcel sizes, protection and usage of land, use of agricultural lands for cultivation purposes, land consolidation, and distribution.

However, this law is mostly criticized for the determination of parcel sizes; whereas the minimum separable parcel size on the agricultural lands is $5000 \mathrm{~m}^{2}$ by the Registry Law, by the law of Land Protection and Land Use Law, according to this law it is "the smallest area on which agricultural actions can be performed economically and agricultural area parcel size that is not be fractioned any more as determined by the ministry of agriculture according to social, economical, ecological, and technical specifications of specific regions and areas. Except the areas required for public investments, agricultural areas can not be divided into smaller parts as determined previously as agricultural land parcels. Parcelling can not be done in areas inherited if sufficient parcels can not be formed. Common use, renting or selling are the only acceptable practices. It is indicated that the parcel area can not be less than as defined by land norm value. As the land norm will have differences regarding the regions, smallest separable area has been a matter of public discussion and repudiated values by the public are defined as 2 hectars in certain agriculture lands and specific crop areas, 0,5 hectar in planted agricultural areas, 0,3 hectar in greenhouse cultivation, and at least 2 hectars in marginal agriculture lands. 


\section{CONCLUSION AND SUGESSTIONS}

Diverse problems have been encountered during each stage of land reform by the many states that have implemented land reform long before the Republic of Turkey. Although there will be Turkey specific prblems, the problems, of the states that have implemented land reform as well as the solutions to these, will be largely similar. Thus, implementing a land reform by taking advantage of the experiences and expertise of the states that have implemented land reforms long before Turkey will be possible. Yet focusing on the specific requirements of Turkey and producing appropriate solutions to these special conditions will prepare the ground for a more successful land reform and prepare the ground for a more just and participatory democratic structure.

It is necessary to pay particular attention to the following facts regarding this topic about the practices of the countries: After the implementation of land reform, in the areas that underwent land reform, many times expected outcomes are not achieved and the success dimnished due to reasons such as insufficient loans, lack of personel to inform and lead farmers, and delays in title deed transactions of the newly distributed land. Moreover, in oreder to keep his small fields, farmers need loans, technical know-how and cooperratives. Therore, in order to educate the farmers about sustainable agriculture and relevant techniques, courses openend to educate the villagers in the areas that underwent land reform.

Following Turkey specific issues bearing the potential of making land reform practices difficult are to be considered:

- Owners of vast land will be against the implementation of land reform. These objections will lead sometimes to political pressures and other times to social pressures.

- Insufficient employment opportunities in nonagricultural sectors and fast population growth-rate will be among the challenges faced in land refom practices. Yet these are far beyond the problems that can be solved through agrarian reforms.

- Financial problems. There will be major monetary issues about meeting the expropriation costs. Therefore, before any land reform attempt, financial resources are to be considered right form the beginning.

- There will be various problems in the valuation process. The diversity in the soil structure, climatic and geographical variations if considered, means that there will be various problems.

- Political pressures, disputes, and social unrest resulting are points that will eliminate the excitement during land reform implementation.
- The bound of the peasants living in rural areas on a small piece of land will be among the problems faced during the implementation of land reform.

\section{REFERENCES}

Besley, Timothy, Leight, Jessica, Pande, Rohini, Rao, Vijayendra, 2016. Long-run impacts of land regulation: Evidence from tenancy reform in India, Journal of Development Economics, Volume 118, Pages 72-87.

Hartvigsen, M., 2014. Land reform and fragmentation in Central and Eastern Europe, Land Use Policy, 36, pp. 330-341.

Suicmez B., and Guler N., 2005. Türkiye'de Toprak Reformu Sorunsalı ve TMMOB, Toprak Reformu Kongresi 11 - 13 Kasım, Şanlıurfa, Türkiye.

Stein, T., Holden, and Hosaena, Ghebru, 2016. Land tenure reforms, tenure security and food security in poor agarian economies: Causal linkages and research gaps, Global Food Security, Volume 10, Pages 21-28.

Stibbe, B., and Dunkley, G., 1997. Land Reform and Land Policy, Beirut, 6-8 October.

Toklu N., 2010. Evaluation Of Land Reform Policies in Turkey, University of Selcuk, Graduate School of Natural and Applied Sciences, Master Thesis, Konya, Turkey.

Ulger, N., E, and Cay, T., 2012. An Assessment About Land Consolidation In Turkey, Fig Working Week 2012, Rome, Italy, 6-10 May.

Anonymus, 1995. Tarım Reformu Genel Müdürlüğü Faaliyet Raporu, Ankara, Türkiye.

Anonymus, 2012. Tarım Reformu Genel Müdürlüğü Faaliyet Raporu, Ankara, Türkiye.

URL 1, http://nebizenginli.blogcu.com. (Accessed 17 April 2013)

URL 2, http://tarim.gov.tr. (Accessed 12 February 2014) .

Copyright (C) International Journal of Engineering and Geosciences (IJEG). All rights reserved, including the making of copies unless permission is obtained from the copyright proprietors. 